\title{
A New Mn-Salen Micellar Nanoreactor for Enantioselective Epoxidation of Alkenes in Water
}

\author{
Francesco P. Ballistreri ${ }^{1}$, Rosa Maria Toscano ${ }^{1}$, Maria Emanuela Amato ${ }^{1}$, Andrea Pappalardo ${ }^{1,2}$, \\ Chiara M. A. Gangemi ${ }^{1}$, Sofia Spidalieri ${ }^{1}$, Roberta Puglisi ${ }^{1}$ and Giuseppe Trusso Sfrazzetto ${ }^{1, *}$ (1) \\ 1 Department of Chemical Sciences, University of Catania, Viale Andrea Doria 6, 95125 Catania, Italy; \\ fballistreri@unict.it (F.P.B.); rmtoscano@unict.it (R.M.T.); eamato@dipchi.unict.it (M.E.A.); \\ andrea.pappalardo@unict.it (A.P.); gangemichiara@unict.it (C.M.A.G.); sofiaspidalieri@gmail.com (S.S.); \\ puglisi.r@studium.unict.it (R.P.) \\ 2 University of Catania Research Unit (I.N.S.T.M.) UdR of Catania, Viale A. Doria 6, 95125 Catania, Italy \\ * Correspondence: giuseppe.trusso@unict.it; Tel.: +39-095-738-5148
}

Received: 28 February 2018; Accepted: 22 March 2018; Published: 25 March 2018

\begin{abstract}
A new chiral Mn-salen catalyst, functionalized with a long aliphatic chain and a choline group, able to act as surfactant catalyst for green epoxidation in water, is here described. This catalyst was employed with a commercial surfactant (CTABr) leading to a nanoreactor for the enantioselective epoxidation of some selected alkenes in water, using $\mathrm{NaClO}$ as oxidant. This is the first example of a nanoreactor for enantioselective epoxidation of non-functionalized alkenes in water.
\end{abstract}

Keywords: epoxidation; water; enantioselectivity; nanoreactor; Mn-salen

\section{Introduction}

Water is an abundant molecule in nature and, due to its diffusion, cost, non-toxicity, and environmental compatibility, is probably one of the most desirable solvents for reactions. In fact, organic solvents are commonly used in the pharmaceutical and chemical industries as reaction media; however, for toxicological and environmental pollution reasons [1], industries aspire to reduce the number and amount of solvents applied in a drug or chemical production. However, the use of water as solvent for organic synthesis is limited by the low solubility of organic compounds and the facile decomposition of many active species in water. These drawbacks have recently been resolved by the use of nanocapsular systems [2] and micelles [3], which dissolve and stabilize organic substrates in water and, in some examples, act as molecular reactors for organic synthesis [4-8].

Olefin epoxidation is an important and useful reaction because it leads to a wide range of organic compounds with significant applications in several technological fields [9]. In particular, chiral Mn(III)-salen complexes have been used as catalysts to obtain chiral epoxides, which represent an essential target due to the importance of enantiomerically pure compounds in industry and pharmaceuticals [10-12]. In this context, many efforts have been addressed to leave behind the "poor eco-friendly conditions" (e.g., the use of organic solvent and reaction with strong conditions) and move toward more efficient and eco-compatible reactions, by using efficient heterogeneous catalysts [13-16] and/or reactions in aqueous media [3]. However, few examples of enantioselective epoxidation in water are reported in the literature [17-22]. A possible solution can be found by using a self-assembly process to obtain amphiphilic or self-assembled nanostructures [23-25], able to solubilize organic substrates in water.

Recently, our research group has developed new protocols to obtain epoxides with high enantioselectivity in water exploiting micelles, in which the surfactant act as co-ligand for a chiral $\mathrm{Mn}$ (III)-salen catalyst [17,18]. In these systems, the micellar catalyst acts as a nanoreactor for the epoxidation reaction. 
Here we present the design, synthesis, and catalytic application of a new nanoreactor, in which chiral $\mathrm{Mn}$ (III)-salen catalyst 1-Mn is itself a surfactant. Micellar nanoreactor consists in catalyst 1-Mn and cetyltrimethylammonium bromide (CTABr), mixed in an appropriate ratio (see Figure 1). Epoxidation results obtained with selected alkenes confirm the ability of our system to act as enantioselective catalyst in water. To the best of our knowledge, this is the first example of chiral nanoreactor able to efficiently catalyze enantioselective epoxidation in pure water.

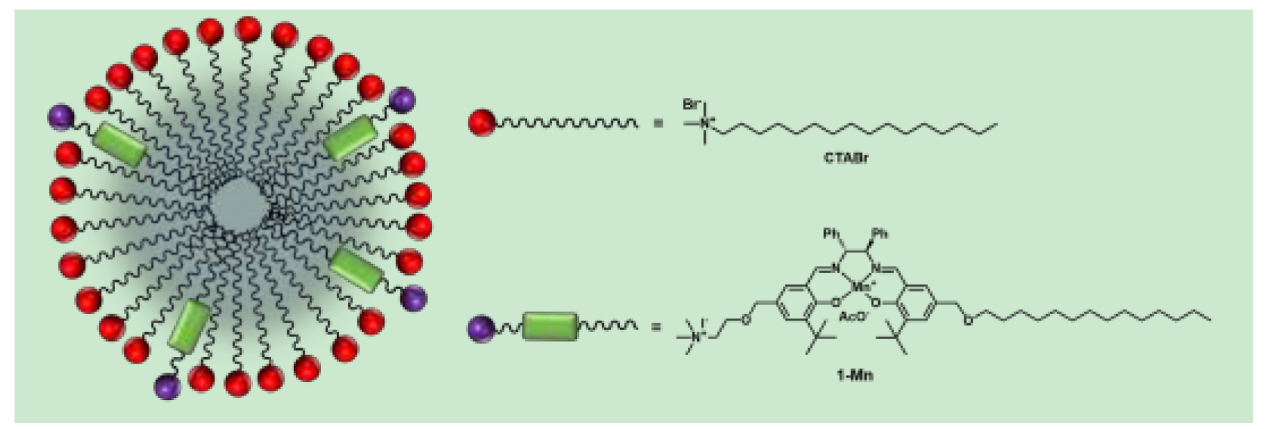

Figure 1. Schematic representation of the micellar nanoreactor and chemical structure of the catalyst 1-Mn and CTABr.

\section{Results and Discussion}

Surfactant catalyst 1-Mn was synthesized according the multi-step pathway shown in Scheme 1. In the first step, 3-(tert-butyl)-2-hydroxybenzaldehyde was reacted with aqueous paraformaldehyde and $\mathrm{HCl}$, leading to the 5-chloromethylated Compound 2 in high yield (95\%) [26]. The reaction of 2 with a stoichiometric amount of tetradecanol in the presence of sodium hydroxide allowed for the selective introduction of the long aliphatic chain in 5-position, fundamental for the surfactant activity, (Compound 3, yield 32\%). Ethanolamine was hypermethylated by reaction with an excess of methyl iodide, in the presence of potassium carbonate, thus obtaining choline iodide 4 in almost quantitative yield. The choline derivative 4 was covalently bound to the aldehyde 2 following the same procedure used to prepare the aliphatic aldehyde 3 . Thus, using an equimolar ratio of 2 and 4 in basic conditions, the water-soluble choline-aldehyde 5 was synthesized in $31 \%$ yield. The salen moiety was assembled using the $(1 R, 2 R)$-diphenyl-ethylendiamino-monochloride 6 [27,28], which, in the presence of the aldehyde 3, afforded the mono-imino-amine-monochloride 7 in quantitative yield. Finally, surfactant chiral salen ligand $\mathbf{1}$ was obtained by condensation of $\mathbf{5}$ and 7, in the presence of triethylamine (yield $67 \%$ ). This strategy is the most viable way to obtain a "non-symmetrical salen ligand" in high yield [29-31]. The water-soluble manganese catalyst 1-Mn was obtained in quantitative yield by addition of manganese acetate to the corresponding chiral ligand 1 . Compounds were fully characterized by NMR and ESI-MS (see Supplementary Materials).

The micellar nanoreactor was assembled using 1-Mn and cetyltrimethylammonium bromide (CTABr) as co-surfactant in a different molar ratio (see Table 1). We selected a cationic surfactant to obtain a micellar surface fully covered by the same positive charges. In addition, catalyst was designed in order to confine the catalytic metal center inside the hydrophobic region of the nanoreactor (see Figure 1), in contrast with our previous works where it was located on the Stern layer $[17,18]$. We think the catalytic site sequestered in the interior of micelles should lead to higher reaction rates, due to a proximity effect with the alkene inside the core of a micelle. 

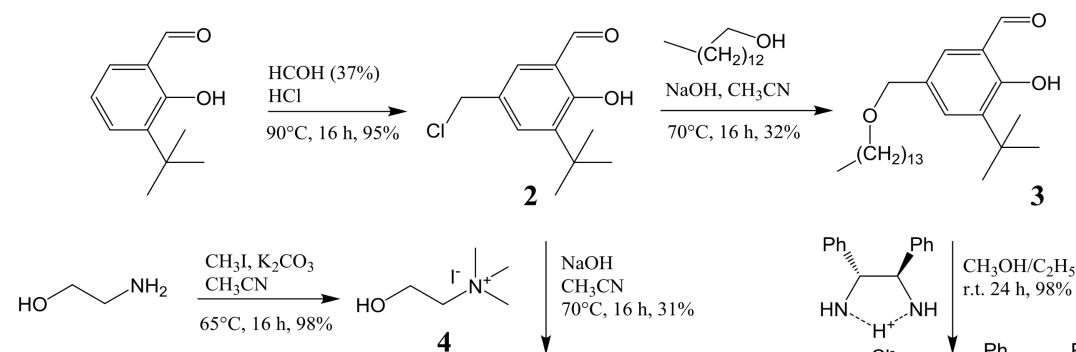$$
2
$$

3

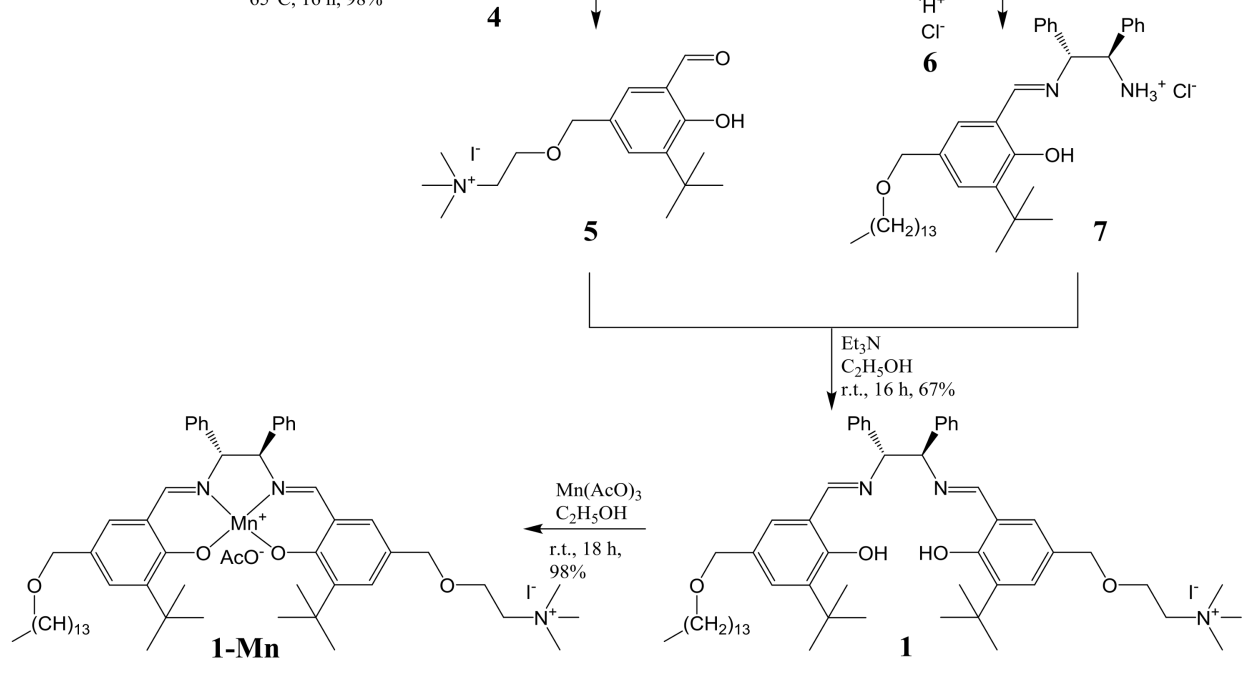

Scheme 1. Synthesis of catalyst 1-Mn.

Micellar nanoreactor was characterized by DOSY measurements. In particular, diffusion coefficient data allowed us to calculate the hydrodynamic radius of the micelle [32-36]. The diffusion coefficient of a $0.03 \mathrm{M}$ solution of CTABr in $\mathrm{D}_{2} \mathrm{O}$ (the same concentration used in the epoxidation reaction) is $1.20 \times 10^{-10} \mathrm{~m}^{2} \mathrm{~s}^{-1}$, corresponding to a hydrodynamic radius of ca. $2.15 \mathrm{~nm}$ (see Section 3) and thus in accordance with the formation of a micelle (the c.m.c. of CTABr is $8.6 \times 10^{-4} \mathrm{M}$ ). The same measurements were performed with a $0.03 \mathrm{M}$ solution of $\mathrm{CTABr}$ and $1 \mathrm{mM}$ 1-Mn in $\mathrm{D}_{2} \mathrm{O}$, and a diffusion coefficient of $1.17 \times 10^{-10} \mathrm{~m}^{2} \mathrm{~s}^{-1}$ was found (hydrodynamic radius of ca. $2.21 \mathrm{~nm}$, see Section 3), thus confirming that the presence of our catalyst does not modify the dimension of the micelle.

Once the presence of micellar systems, with and without the addition of 1-Mn, was confirmed, we tested our system as nanoreactor in the enantioselective epoxidation of some selected aromatic alkenes, in particular 6-cyano-2,2-dimethylchromene, 1,2-dihydronaphthalene, and cis- $\beta$-ethylstyrene in water, using $\mathrm{NaClO}$ as the oxidant. Results are summarized in Table 1. In fact, as reported by Corey et al., alkenes that are conjugated with a $\pi$-system are ideal substrates for enantioselective epoxidation by using a Jacobsen catalytic system [37].

Due to the high reactivity of 6-cyano-2,2-dimethylchromene in the oxidation reactions [38], using $0.03 \mathrm{M} \mathrm{CTABr}$ and $5 \%$ catalyst, total conversion in epoxide is complete in $3 \mathrm{~h}$, with an enantiomeric excess of ca. $83 \%$ (Entries 1-2). The increase in concentration of CTABr from 0.03 to $0.06 \mathrm{M}$ does not affect enantioselectivity and conversion values (Entries 3-4). Enantiomeric excess values with 1,2-dihydronaphthalene were also in the range of $80-84 \%$, confirming the ability of the nanoreactor to achieve enantioselectivity. As shown in our previous works [17,18], 1,2-dihydronaphthalene presents lower reaction rates compared to 6-cyano-2,2-dimethylchromene. 
Table 1. Enantioselective epoxidation of 6-CN-2,2-dimethylchromene, 1,2-dihydronaphthalene, and cis- $\beta$-ethylstyrene with $\mathrm{NaClO}$ catalyzed by micellar nanoreactor containing 1-Mn and CTABr in $\mathrm{H}_{2} \mathrm{O}$ at $25^{\circ} \mathrm{C}^{\text {a }}$.

\begin{tabular}{|c|c|c|c|c|c|c|}
\hline Alkene & Entry & [CTABr] (M) & $1-\mathrm{Mn}(\%)^{\mathrm{b}}$ & Time (h) & e.e. $(\%)^{c}$ & Conv. $(\%)^{c}$ \\
\hline & 1 & 0.03 & 5 & 1 & $83^{e}$ & 85 \\
\hline & 2 & 0.03 & 5 & 3 & $82^{\mathrm{e}}$ & 100 \\
\hline & 3 & 0.06 & 5 & 1 & $83^{\mathrm{e}}$ & 87 \\
\hline & 4 & 0.06 & 5 & 3 & $83^{\mathrm{e}}$ & 100 \\
\hline & 5 & 0.03 & 5 & 1 & $83^{f}$ & 17 \\
\hline & 6 & 0.03 & 5 & 8 & $82^{f}$ & 46 \\
\hline & 7 & 0.03 & 10 & 8 & $84^{\mathrm{f}}$ & 64 \\
\hline & 8 & 0.06 & 10 & 1 & $80^{\mathrm{f}}$ & 76 \\
\hline & 9 & 0.06 & 10 & 3 & $83^{\mathrm{f}}$ & 100 \\
\hline & 10 & 0.03 & 5 & 1 & $50 \mathrm{~g}$ & 73 \\
\hline & 11 & 0.03 & 5 & 2 & $51^{g}$ & 100 \\
\hline & $12^{d}$ & 0.015 & 10 & 1 & $56^{\mathrm{g}}$ & 88 \\
\hline & $13^{\mathrm{d}}$ & 0.015 & 10 & 4 & $57 \mathrm{~g}$ & 100 \\
\hline & $14^{\mathrm{d}}$ & 0.03 & 10 & 1 & $56^{g}$ & 86 \\
\hline & $15^{\mathrm{d}}$ & 0.03 & 10 & 4 & $58^{g}$ & 100 \\
\hline & $16^{\mathrm{d}}$ & 0.06 & 10 & 1 & $58^{g}$ & 85 \\
\hline & $17^{\mathrm{d}}$ & 0.06 & 10 & 4 & $57 \mathrm{~g}$ & 100 \\
\hline
\end{tabular}

\footnotetext{
${ }^{\mathrm{a}}$ In all experiments [alkene] $=[\mathrm{NaClO}]=1.17 \times 10^{-2} \mathrm{M}$, buffered with $1 \mathrm{~mL}$ of $0.05 \mathrm{M} \mathrm{Na}_{2} \mathrm{HPO}_{4}$ at $\mathrm{pH} 11.2$ in a total volume of $2 \mathrm{~mL}$ [39]. ${ }^{\mathrm{b}}$ referred to the alkene concentration. ${ }^{\mathrm{c}}$ Enantiomeric Excess (e.e.) and Conversion values (Conv.) were determined by Gas chromatographic (GC) analysis using a chiral column (see Section 3 ) and $n$-dodecane as internal standard. ${ }^{d} \mathrm{NaClO}$ was added dropwise in $1 \mathrm{~h} .{ }^{\mathrm{e}}$ config. $(3 R, 4 S)$ determined by measuring the optical rotation. ${ }^{\mathrm{f}}$ config. $(1 R, 2 S)$ determined by measuring the optical rotation. ${ }^{\mathrm{g}}$ Enantiomeric excess (e.e.) value is referred to the to the major cis epoxide (cis/trans $=4)$.
}

In fact, under the same conditions, after $1 \mathrm{~h}$ of reaction, only a $17 \%$ conversion was obtained (Entry 1 vs. Entry 5). After 8 h of reaction, a $46 \%$ conversion value was observed (Entry 6). The increase in concentration of the catalyst 1-Mn (10\% respect to the substrate) was not sufficient to reach full conversion, affording a conversion of $64 \%$ (Entry 7). With $0.06 \mathrm{M} \mathrm{CTABr}$, conversions increased to $76 \%$ after $1 \mathrm{~h}$ and $100 \%$ after $3 \mathrm{~h}$ (Entries 8 and 9, respectively). These results suggest strong contribution from the nature of the substrate to the reaction rate.

This hypothesis was confirmed considering cis- $\beta$-ethylstyrene: using $0.03 \mathrm{M} \mathrm{CTABr}$ and $5 \%$ catalyst, conversion reached $73 \%$ in $1 \mathrm{~h}$ and $100 \%$ after $2 \mathrm{~h}$. However, the enantioselectivity value observed was 51\% (Entries 10-11).

In order to increase enantioselectivity with this alkene, we evaluated the effect of CTABr surfactant concentration, performing epoxidation reactions at $0.015,0.03$, and $0.06 \mathrm{M} \mathrm{CTABr}$, using $10 \%$ catalyst (Entries 12-17). We noted that the 10\% catalyst amount led to a slight improvement in enantioselectivity $(56-58 \%)$, while the reaction rates remained quite similar.

Noteworthy, the simple CTABr micelle containing selected alkenes in water, after the addition of $\mathrm{NaClO}$, leads to a racemic mixture of epoxides; in the classic biphasic system $\left(\mathrm{CH}_{2} \mathrm{Cl}_{2} / \mathrm{H}_{2} \mathrm{O}\right)$, this reaction has never been observed [10-12,40]. Thus, the presence of the chiral catalyst is essential to catalyze the enantioselective epoxidation of alkenes.

The recovery of the catalyst was also evaluated. In particular, after complete conversion of the starting alkene (we tested recovery using 1,2-dihydronaphthalene as substrate), 1-Mn was extracted by an addition of dichlorometane. The organic phase was dried, and the resulting catalyst was reused in a new epoxidation, using the same conditions reported in Entry 9 of Table 1. Conversions and enantiomeric excess are reported in Figure 2. After five cycles, enantiomeric excess was constant, demonstrating the robustness of the catalyst. 
Finally, we tested the sustainability of our protocol measuring the EcoScale of our process [41,42]. This scale takes into consideration the yield of the reaction, combined to several parameters, such as the price of reaction components, the safety of reagents, the technical setup, the temperature/time, the workup, and the purification. These parameters influence the quality of reaction conditions. After calculation of the appropriate "penalty points," the EcoScale value can be obtained. An ideal "green" reaction has an EcoScale of 100. In our case, an EcoScale value of 93 was calculated, thus confirming an excellent protocol.

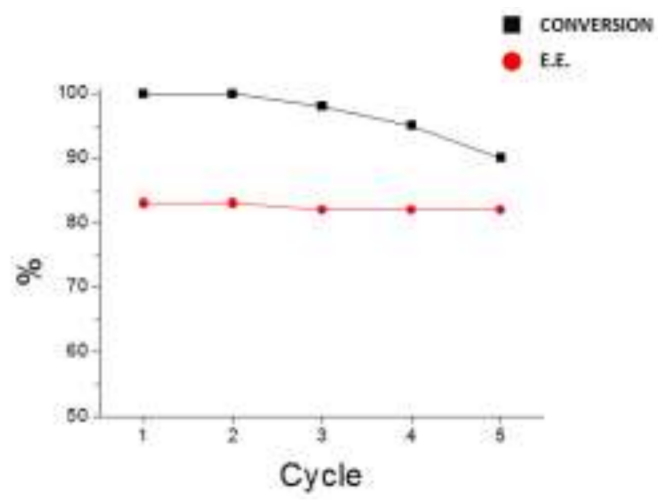

Figure 2. Enantiomeric excess (E.E.) variations and conversion values measured after $3 \mathrm{~h}$ by recycling 1-Mn in the epoxidation of 1,2-dihydronaphthalene. Reaction conditions are reported in Entry 9 of Table 1.

\section{Materials and Methods}

\subsection{General}

The NMR experiments were carried out at $27^{\circ} \mathrm{C}$ on a Varian UNITY Inova $500 \mathrm{MHz}$ spectrometer $\left({ }^{1} \mathrm{H}\right.$ at $499.88 \mathrm{MHz},{ }^{13} \mathrm{C}-\mathrm{NMR}$ at $125.7 \mathrm{MHz}$, Varian-Agilent, Santa Clara, CA, USA) equipped with pulse field gradient module ( $\mathrm{Z}$ axis) and a tunable $5 \mathrm{~mm}$ Varian inverse detection probe (ID-PFG). ESI mass spectra were acquired on a API $2000^{\mathrm{TM}}$ AB Sciex (Milano, Italy) using $\mathrm{MeOH}$ (positive ion mode). All chemicals were reagent grade and were used without further purification. Enantiomeric excesses were determined by GC analysis with a Perkin Elmer Capillary (Perkin Elmer, Waltham, MA, USA) using a dimethylpentyl-beta (DIMEPEBETA-086) chiral column $(25 \mathrm{~m} \times 0.25 \mathrm{~mm}$ ID, $0.25 \mu \mathrm{m}$ film) for 6-cyano-2,2-dimethylchromene; DiAcTBuSiliBETA-ov-1701 chiral column ( $25 \mathrm{~m} \times 0.25 \mathrm{~mm}$ ID, $0.25 \mu \mathrm{m}$ film) for cis- $\beta$-ethylstyrene and dimethyl-pentyl-beta (DMePeBETACDX) chiral column $(25 \mathrm{~m} \times 0.25 \mathrm{~mm}$ ID, $0.25 \mu \mathrm{m}$ film) for 1,2-dihydronaphthalene. The absolute configuration of the obtained epoxides were determined by measuring the optical rotation with a polarimeter. Absolute configurations were assigned by comparison of the measured $[\alpha]_{D}{ }^{20}$ values with those reported in the literature [43]. ${ }^{1} \mathrm{H}-\mathrm{NMR}$ characterizations of Compounds $\mathbf{2}$ and $\mathbf{4}$ are according to those reported in the literature [15].

\subsection{DOSY Measurements}

The DOSY technique provides information about the size of the molecular aggregate in solution. In fact, by means of the Stokes-Einstein equation, the diffusion coefficient of the CTABr can be converted into its hydrodynamic radius $R_{h}$, and this value can be compared with the calculated radius obtained by the Hyperchem-minimized structure of the surfactant (in the maximum extension, CTABr is ca. $2 \mathrm{~nm}$, leading a micellar aggregates of ca. $4 \mathrm{~nm}$ of diameter). Thus, combining the diffusion coefficient of the $\operatorname{CTABr}\left(D=1.20 \times 10^{-10} \mathrm{~m}^{2} \mathrm{~s}^{-1}\right)$ with the viscosity of $\mathrm{D}_{2} \mathrm{O}$ at $298 \mathrm{~K}$ in the Stokes-Einstein equation ( $R=\mathrm{k}_{\mathrm{B}} T / 6 \pi \eta D$, where $\mathrm{k}_{\mathrm{B}}$ is the Boltzmann constant, $T$ is the absolute temperature, and $\eta$ is the viscosity of $\mathrm{D}_{2} \mathrm{O}$ at $\left.298 \mathrm{~K}(0.85 \mathrm{cP})\right)$, a hydrodynamic radius $R_{h}(\exp )=2.15 \mathrm{~nm}$ was obtained. The same treatment for the nanoreactor containing CTABr and 1-Mn give a $R_{h}(\exp )=2.21 \mathrm{~nm}$. 


\subsection{Synthesis and Characterization}

Synthesis of the aldehyde 2 . An amount of $0.720 \mathrm{~mL}(8.6 \mathrm{mmol})$ of aqueous formaldehyde and $9 \mathrm{~mL}$ of $\mathrm{HCl}$ conc. were added to $1 \mathrm{~g}(5.61 \mathrm{mmol})$ of the 3-tBut-salicylaldehyde. The mixture was stirred at $90{ }^{\circ} \mathrm{C}$ for $16 \mathrm{~h}$. The reaction was cooled to room temperature, obtaining a precipitate. Diethyl ether was added to the aqueous solution, extracted, and dried with $\mathrm{Na}_{2} \mathrm{SO}_{4}$. Evaporation of the solvent afforded Compound 2 (yield 95\%). ${ }^{1} \mathrm{H}-\mathrm{NMR}\left(500 \mathrm{MHz}, \mathrm{CDCl}_{3}\right) \delta 11.85(\mathrm{~s}, 1 \mathrm{H}, \mathrm{OH}), 9.87(\mathrm{~s}, 1 \mathrm{H}, \mathrm{CHO})$, $7.53(\mathrm{~d}, J=2.5 \mathrm{~Hz}, 1 \mathrm{H}, \mathrm{ArH}), 7.44(\mathrm{~d}, J=2.5 \mathrm{~Hz}, 1 \mathrm{H}, \mathrm{ArH}), 4.59\left(\mathrm{~s}, 2 \mathrm{H},-\mathrm{CH}_{2} \mathrm{Cl}\right), 1.43\left(\mathrm{~s}, 9 \mathrm{H}, \mathrm{Ar}-\mathrm{CH}_{3}\right)$. Anal. Calcd. For $\mathrm{C}_{12} \mathrm{H}_{15} \mathrm{ClO}_{2}$ : C, 63.58; $\mathrm{H}, 6.67 ; \mathrm{Cl}, 15.64$. Found $\mathrm{C}, 63.51 ; \mathrm{H}, 6.62 ; \mathrm{Cl}, 15.58$.

Synthesis of the aldehyde 3 . Tetradecanol $(629 \mathrm{mg}, 2.95 \mathrm{mmol})$ was dissolved in $25 \mathrm{~mL}$ of acetonitrile dry, and $118 \mathrm{mg}(2.95 \mathrm{mmol})$ of $\mathrm{NaOH}$ was added. The mixture was heated at $70{ }^{\circ} \mathrm{C}$ for $4 \mathrm{~h}$, and $700 \mathrm{mg}$ $(3.10 \mathrm{mmol}$ ) of the aldehyde 2 , dissolved in $15 \mathrm{~mL}$ of acetonitrile dry, were then added dropwise in $1 \mathrm{~h}$. The reaction was stirred at $70{ }^{\circ} \mathrm{C}$ overnight under nitrogen. Then, the solvent was removed under reduced pressure, and the crude product was dissolved in $\mathrm{CH}_{2} \mathrm{Cl}_{2}$ and washed with water. The organic phase was dried with $\mathrm{Na}_{2} \mathrm{SO}_{4}$ and purified by column chromatography (n-hexane/EtOAc 98/2) affording the pure Compound 3 as oil (yield 32\%). ${ }^{1} \mathrm{H}-\mathrm{NMR}\left(500 \mathrm{MHz}, \mathrm{CDCl}_{3}\right) \delta 11.76(\mathrm{~s}, 1 \mathrm{H}, \mathrm{OH}), 9.87(\mathrm{~s}, 1 \mathrm{H}$, $\mathrm{CHO}), 7.49(\mathrm{~d}, J=2.0 \mathrm{~Hz}, 1 \mathrm{H}, \mathrm{ArH}), 7.37(\mathrm{~d}, J=2.0 \mathrm{~Hz}, 1 \mathrm{H}, \mathrm{ArH}), 4.44\left(\mathrm{~s}, 2 \mathrm{H}, \mathrm{Ar}-\mathrm{CH}_{2}-\mathrm{O}\right), 3.48(\mathrm{t}$, $\left.J=6.5 \mathrm{~Hz}, 2 \mathrm{H}, \mathrm{O}-\mathrm{CH}_{2}-\mathrm{CH}_{2}-\right), 1.62\left(\mathrm{~m}, 2 \mathrm{H}, \mathrm{O}-\mathrm{CH}_{2}-\mathrm{CH}_{2}-\right), 1.42\left(\mathrm{~s}, 9 \mathrm{H}, \mathrm{Ar}-\mathrm{CH}_{3}\right), 1.25-1.30(\mathrm{~m}, 22 \mathrm{H}$, $\left.\mathrm{O}-\mathrm{CH}_{2}-\mathrm{CH}_{2}-\left(\mathrm{CH}_{2}\right)_{11}-\mathrm{CH}_{3}\right), 0.88\left(\mathrm{t}, J=7.5 \mathrm{~Hz}, 3 \mathrm{H}, \mathrm{O}-\mathrm{CH}_{2}-\mathrm{CH}_{2}-\left(\mathrm{CH}_{2}\right)_{11}-\mathrm{CH}_{3}\right) .{ }^{13} \mathrm{C}-\mathrm{NMR}(125 \mathrm{MHz}$, $\left.\mathrm{CDCl}_{3}\right) \delta 197.0,160.7,138.3,133.9,130.9,129.3,120.3,72.2,70.7,34.8,31.9,29.7,29.66,29.61,29.47,26.34$, 29.2. ESI-MS $m / z 405.3[\mathrm{M}+\mathrm{H}]^{+}$. Anal. Calcd. For $\mathrm{C}_{26} \mathrm{H}_{44} \mathrm{O}_{3}: \mathrm{C}, 77.18 ; \mathrm{H}, 10.96$. Found $\mathrm{C}, 77.09 ; \mathrm{H}, 10.89$.

Synthesis of the choline iodide 4 . A suspension containing $2 \mathrm{~g}(32.7 \mathrm{mmol})$ of ethanolamine, $9 \mathrm{~g}(65.4 \mathrm{mmol})$ of $\mathrm{K}_{2} \mathrm{CO}_{3}$ anhydrous, and $23.11 \mathrm{~g}(163 \mathrm{mmol})$ of $\mathrm{CH}_{3} \mathrm{I}$ in $25 \mathrm{~mL}$ of acetonitrile dry was stirred vigorously overnight at $65^{\circ} \mathrm{C}$ under nitrogen. Then, reaction was filtered to remove the base, and solvent was removed under reduced pressure to yield pure hypermethylated Compound 4 (yield $98 \%$ ). ${ }^{1} \mathrm{H}-\mathrm{NMR}$ $\left(500 \mathrm{MHz}, \mathrm{D}_{2} \mathrm{O}\right) \delta 4.10\left(\mathrm{~m}, 2 \mathrm{H}, \mathrm{OH}-\mathrm{CH}_{2}-\right), 3.56\left(\mathrm{t}, J=5.0 \mathrm{~Hz}, 2 \mathrm{H},-\mathrm{CH}_{2}-\mathrm{N}\right), 3.25\left(\mathrm{~s}, 9 \mathrm{H}, \mathrm{N}\left(\mathrm{CH}_{3}\right)_{3}\right)$. Anal. Calcd. For $\mathrm{C}_{5} \mathrm{H}_{14} \mathrm{INO}$ : C, 25.99; H, 6.11; N, 6.06. Found C, 25.91; H, 6.03; N, 6.01.

Synthesis of the choline-aldehyde 5 . Choline iodide $4(459 \mathrm{mg}, 1.98 \mathrm{mmol})$ was dissolved under nitrogen in $40 \mathrm{~mL}$ of acetonitrile dry. Then, $79 \mathrm{mg}(1.98 \mathrm{mmol})$ of $\mathrm{NaOH}$ was added, and the mixture was stirred at $70{ }^{\circ} \mathrm{C}$ for $3 \mathrm{~h}$. Then, a solution of the aldehyde $2(463 \mathrm{mg}, 2.05 \mathrm{mmol}$, in $25 \mathrm{~mL}$ of acetonitrile dry) was added dropwise in $1 \mathrm{~h}$. The reaction was stirred under nitrogen overnight at $70^{\circ} \mathrm{C}$. The reaction was monitored by TLC following the disappearance of the starting aldehyde 2 . The reaction was cooled to room temperature, the solvent was removed under reduced pressure, and Compound $\mathbf{5}$ (yield 31\%) was purified by alumina column (from $\mathrm{CH}_{2} \mathrm{Cl}_{2} 100 \%$ to $\left.\mathrm{CH}_{2} \mathrm{Cl}_{2} / \mathrm{CH}_{3} \mathrm{OH} 95 / 5\right) .{ }^{1} \mathrm{H}-\mathrm{NMR}(500 \mathrm{MHz}$, $\left.\mathrm{CDCl}_{3}\right) \delta 11.87(\mathrm{~s}, 1 \mathrm{H}, \mathrm{OH}), 9.91(\mathrm{~s}, 1 \mathrm{H}, \mathrm{CHO}), 7.45(\mathrm{~d}, J=2.0 \mathrm{~Hz}, 1 \mathrm{H}, \mathrm{ArH}), 7.43(\mathrm{~d}, J=2.0 \mathrm{~Hz}, 1 \mathrm{H}$, $\mathrm{ArH}), 4.56\left(\mathrm{~m}, 2 \mathrm{H},-\mathrm{CH}_{2}-\mathrm{N}\left(\mathrm{CH}_{3}\right)_{3}\right), 4.00\left(\mathrm{~m}, 4 \mathrm{H}, \mathrm{Ar}-\mathrm{CH}_{2}-\mathrm{O}\right.$ and $\left.\mathrm{O}-\mathrm{CH}_{2}-\mathrm{CH}_{2}-\right), 3.44\left(\mathrm{~s}, 9 \mathrm{H}, \mathrm{N}\left(\mathrm{CH}_{3}\right)_{3}\right)$, $1.42\left(\mathrm{~s}, 9 \mathrm{H}, \mathrm{Ar}-\mathrm{CH}_{3}\right) .{ }^{13} \mathrm{C}-\mathrm{NMR}\left(125 \mathrm{MHz}, \mathrm{DMSO}-d_{6}\right)$ 109.81, 160.71, 136.95, 129.17, 128.80, 122.16, 117.74, 66.94, 55.14, 53.20, 45.71, 22.52, 14.39. ESI-MS $m / z 294.2[\mathrm{M}]^{+}$. Anal. Calcd. For $\mathrm{C}_{17} \mathrm{H}_{28} \mathrm{INO}_{3}$ : C, 48.46; H, 6.70; N, 3.32. Found C, 48.41; H, 6.62; N, 3.28.

Synthesis of the aldehyde 7 . To a solution of $190 \mathrm{mg}(0.766 \mathrm{mmol})$ of $(1 R, 2 R)$-diphenyl-ethylendiaminomonochloride 6 [27,28] dissolved in $20 \mathrm{~mL}$ of a mixture 50/50 of methanol/ethanol was added dropwise $299 \mathrm{mg}(0.740 \mathrm{mmol})$ of aldehyde 3, dissolved in $10 \mathrm{~mL}$ of the same solvent mixture. The reaction was stirred at room temperature for $24 \mathrm{~h}$. Then, the solvent was removed under reduced pressure, and the crude product was washed with a few milliliters of water to remove the starting reagent 6 and filtered, yielding Compound 7 (yield 98\%). ${ }^{1} \mathrm{H}-\mathrm{NMR}\left(500 \mathrm{MHz}, \mathrm{DMSO}-d_{6}\right) \delta 13.36(\mathrm{~s}$, $1 \mathrm{H}, \mathrm{OH}), 8.74(\mathrm{~s}, 1 \mathrm{H}, \mathrm{CHN}), 8.55\left(\mathrm{~s} \mathrm{br}, 3 \mathrm{H}, \mathrm{NH}_{3}\right), 7.36(\mathrm{~m}, 2 \mathrm{H}, \mathrm{ArH}), 7.19-7.29(\mathrm{~m}, 10 \mathrm{H}, \mathrm{ArH}), 5.03$ $\left(\mathrm{d}, J=10 \mathrm{~Hz}, 1 \mathrm{H}, \mathrm{CH}\right.$ methine), $4.88(\mathrm{~d}, J=10.0 \mathrm{~Hz}, 1 \mathrm{H}, \mathrm{CH}$ methine $), 4.35\left(\mathrm{~s}, 2 \mathrm{H}, \mathrm{Ar}-\mathrm{CH}_{2}-\mathrm{O}\right), 3.36$ $\left(\mathrm{t}, J=6.0 \mathrm{~Hz}, 2 \mathrm{H}, \mathrm{O}-\mathrm{CH}_{2}-\mathrm{CH}_{2}-\right), 1.48\left(\mathrm{~m}, 2 \mathrm{H}, \mathrm{O}-\mathrm{CH}_{2}-\mathrm{CH}_{2}-\right), 1.38\left(\mathrm{~s}, 9 \mathrm{H}, \mathrm{ArCH}_{3}\right), 1.19-1.26(\mathrm{~m}, 22 \mathrm{H}$, 
$\left.\mathrm{O}-\mathrm{CH}_{2}-\mathrm{CH}_{2}-\left(\mathrm{CH}_{2}\right)_{11}-\mathrm{CH}_{3}\right), 0.82\left(\mathrm{t}, J=6.5 \mathrm{~Hz}, 3 \mathrm{H}, \mathrm{O}-\mathrm{CH}_{2}-\mathrm{CH}_{2}-\left(\mathrm{CH}_{2}\right)_{11}-\mathrm{CH}_{3}\right) .{ }^{13} \mathrm{C}-\mathrm{NMR}(125 \mathrm{MHz}$, DMSO- $d_{6}$ ) 156.83, 138.65, 133.68, 129.185, 128.98, 128.54, 128.48, 128.02, 126.74, 68.29, 60.73, 57.19, $36.55,32.55,31.29,29.82,29.01,28.70,25.71,25.51,22.10,13.96$. ESI-MS $m / z 599.7$ [M] $^{+}$. Anal. Calcd. For $\mathrm{C}_{40} \mathrm{H}_{59} \mathrm{ClN}_{2} \mathrm{O}_{2}$ : C, 75.62; H, 9.36; N, 4.41. Found: C, 75.54; H, 9.27; N, 4.32.

Synthesis of 1. To a solution of ethanol (30 mL) containing $270 \mathrm{mg}(0.641 \mathrm{mmol})$ of 5 and $406 \mathrm{mg}$ $(0.641 \mathrm{mmol})$ of $7,190 \mu \mathrm{L}$ of triethylamine were added slowly. The mixture was stirred at room temperature overnight. The solvent was then removed under reduced pressure. The salen (1) (yield $67 \%)$ was purified by a neutral alumina column $\left(\mathrm{CH}_{2} \mathrm{Cl}_{2}\right.$ containing $\left.5 \% \mathrm{CH}_{3} \mathrm{OH}\right) .{ }^{1} \mathrm{H}-\mathrm{NMR}(500 \mathrm{MHz}$, $\left.\mathrm{CDCl}_{3}\right) \delta 13.93(\mathrm{~s}, 1 \mathrm{H}, \mathrm{OH}), 13.75(\mathrm{~s}, 1 \mathrm{H}, \mathrm{OH}), 8.38(\mathrm{~s}, 1 \mathrm{H}, \mathrm{CHN}), 8.34(\mathrm{~s}, 1 \mathrm{H}, \mathrm{CHN}), 7.14-7.24$ $(\mathrm{m}, 12 \mathrm{H}, \mathrm{ArH}), 6.97(\mathrm{~m}, 2 \mathrm{H}, \mathrm{ArH}), 4.75\left(\mathrm{~m}, 2 \mathrm{H}, \mathrm{CH}\right.$ methine), 4.39 (s, 2H, Ar- $\left.\mathrm{CH}_{2}-\mathrm{O}\right), 4.31(\mathrm{~s}, 2 \mathrm{H}$, $\left.\mathrm{Ar}-\mathrm{CH}_{2}-\mathrm{O}\right), 3.93\left(\mathrm{~m}, 2 \mathrm{H},-\mathrm{CH}_{2}-\mathrm{N}\left(\mathrm{CH}_{3}\right)_{3}, 3.86\left(\mathrm{~m}, 2 \mathrm{H}, \mathrm{O}-\mathrm{CH}_{2}-\mathrm{CH}_{2}-\mathrm{N}\left(\mathrm{CH}_{3}\right)_{3}\right), 3.43(\mathrm{t}, J=6.5 \mathrm{~Hz}, 2 \mathrm{H}\right.$, $\left.\mathrm{O}-\mathrm{CH}_{2}-\mathrm{CH}_{2}-\right), 3.38\left(\mathrm{~s}, 9 \mathrm{H}, \mathrm{N}\left(\mathrm{CH}_{3}\right)_{3}\right), 1.60\left(\mathrm{~m}, 2 \mathrm{H}, \mathrm{O}-\mathrm{CH}_{2}-\mathrm{CH}_{2}-\right), 1.42\left(\mathrm{~s}, 18 \mathrm{H}, \mathrm{Ar}-\mathrm{CH}_{3}\right), 1.25-1.30$ $\left(\mathrm{m}, 22 \mathrm{H}, \mathrm{O}-\mathrm{CH}_{2}-\mathrm{CH}_{2}-\left(\mathrm{CH}_{2}\right)_{11}-\mathrm{CH}_{3}\right), 0.88\left(\mathrm{t}, J=7.5 \mathrm{~Hz}, 3 \mathrm{H}, \mathrm{O}-\mathrm{CH}_{2}-\mathrm{CH}_{2}-\left(\mathrm{CH}_{2}\right)_{11}-\mathrm{CH}_{3}\right) .{ }^{13} \mathrm{C}-\mathrm{NMR}$ $\left(125 \mathrm{MHz}, \mathrm{CDCl}_{3}\right) \delta 166.73,166.36,139.30,130.00,129.81,129.73,129.62,128.38,127.96,127.63,79.99$, 73.60, 72.69, 70.50, 63.50, 54.92, 45.87, 31.91, 29.67, 29.29, 26.21, 22.68, 15.49, 14.11, 8.60. ESI-MS $\mathrm{m} / \mathrm{z}$ $874.7[\mathrm{M}]^{+}$. Anal. Calcd. For $\mathrm{C}_{57} \mathrm{H}_{84} \mathrm{IN}_{3} \mathrm{O}_{4}: \mathrm{C}, 68.31 ; \mathrm{H}, 8.45 ; \mathrm{N}, 4.19$. Found: $\mathrm{C}, 68.22 ; \mathrm{H}, 8.36 ; \mathrm{N}, 4.10$.

Synthesis of 1-Mn. In a round bottom flask containing $430 \mathrm{mg}(0.430 \mathrm{mmol})$ of the salen 1 dissolved in $15 \mathrm{~mL}$ of absolute ethanol, $171 \mathrm{mg}(0.643 \mathrm{mmol})$ of manganese (III) acetate dehydrate were added. The mixture was stirred at room temperature overnight. The solvent was then removed under reduced pressure, and the crude product was dissolved in $\mathrm{CH}_{2} \mathrm{Cl}_{2}$ and filtered to remove the excess of manganese (III) acetate. Evaporation of the solvent afforded 1-Mn as a brown precipitate (yield 98\%). ESI-MS m/z $927.5[\mathrm{M}]^{+}$. Anal. Calcd. For $\mathrm{C}_{59} \mathrm{H}_{72} \mathrm{IMnN}_{3} \mathrm{O}_{6}: \mathrm{C}, 64.36 ; \mathrm{H}, 6.59 ; \mathrm{N}, 3.82$. Found: $\mathrm{C}, 64.30$ $\mathrm{H}, 6.51 ; \mathrm{N}, 3.75$.

Enantioselective epoxidation in the nanoreactor. In a typical run, alkene and n-dodecane (internal standard) were added to a stirred solution of surfactant and the catalyst 1-Mn in distilled water $(1 \mathrm{~mL})$ and phosphate buffer ( $1 \mathrm{~mL}, 0.05 \mathrm{M} \mathrm{Na}_{2} \mathrm{HPO}_{4}$ at $\left.\mathrm{pH} 11.2\right)$; after the complete solubilization, $\mathrm{NaClO}$ was added dropwise ( $5 \mu \mathrm{L} / 10 \mathrm{~min})$ to the mixture and the reaction was kept in a round-bottom flask at $25^{\circ} \mathrm{C}$ in a thermostatic bath. After a certain reaction time, the aqueous solution was extracted with $1 \mathrm{~mL}$ of $\mathrm{CH}_{2} \mathrm{Cl}_{2}$. Combined organic extracts were dried over anhydrous $\mathrm{MgSO}_{4}$, reduced to a small volume, and analyzed by GC as described above.

\section{Conclusions}

A new surfactant catalyst, containing a chiral Mn-salen framework, able to catalyze in water enantioselective epoxidation of non-functionalized alkenes, is here presented. Epoxidation reactions were carried out into micellar systems, containing also a commercial surfactant (CTABr), thus forming the first nanoreactor able to achieve enantioselectivity in water. The epoxidation reactions with 6-CN-2,2-dimethylchromene and 1,2-dihydronaphthalene exhibited excellent results, with high conversions and enantioselectivity values. The structure of the surfactant catalyst likely plays a crucial role: in particular, the position of the catalytic metal center with respect to the micellar aggregate leads to different reactivities toward different alkenes. We are working on optimizing the nanoreactor structure: in particular, we believe that the length of the aliphatic moiety of the catalyst is crucial for improving the reactivity of aliphatic alkenes (e.g., cis- $\beta$-ethylstyrene).

Supplementary Materials: The following are available online at http:/ /www.mdpi.com/2073-4344/8/4/129/s1: NMR, gCOSY, and ESI-MS spectra.

Acknowledgments: Dedicated to Prof. Gaetano A. Tomaselli in occasion of his retirement. This work was supported by the University of Catania-Department of Chemical Science (Piano per la Ricerca-Linea Intervento 2).

Author Contributions: F.P.B. and G.T.S. conceived and designed the experiments; G.T.S. and S.S. performed the synthesis; C.M.A.G., R.M.T., and R.P. performed the epoxidation experiments; A.P. and M.E.A. analyzed the data; G.T.S. wrote the paper. 
Conflicts of Interest: The authors declare no conflict of interest.

\section{References and Notes}

1. Welton, T. Solvents and sustainable chemistry. Proc. Math. Phys. Eng. Sci. 2015, 471, 20150502. [CrossRef] [PubMed]

2. Gangemi, C.M.A.; Pappalardo, A.; Trusso Sfrazzetto, G. Applications of supramolecular capsules derived from resorcin[4]arenes, calix[n]arenes and metalloligands: From biology to catalysis. RSC Adv. 2015, 5, 51919-51933. [CrossRef]

3. Kitanosono, T.; Masuda, K.; Xu, P.; Kobayashi, S. Catalytic Organic Reactions in Water toward Sustainable Society. Chem. Rev. 2018, 118, 679-746. [CrossRef] [PubMed]

4. Cotanda, P.; Lu, A.; Patterson, J.P.; Petzetakis, N.; O’Reilly, R.K. Functionalized Organocatalytic Nanoreactors: Hydrophobic Pockets for Acylation Reactions in Water. Macromolecules 2012, 45, 2377-2384. [CrossRef]

5. Scarso, A. Micellar Nanoreactor. In Encyclopedia of Inorganic and Bioinorganic Chemistry; John Wiley \& Sons Ltd.: Chichester, UK, 2016; pp. 1-16. [CrossRef]

6. Hou, S.; Xie, C.; Yu, F.; Yuan, B.; Yu, S. Selective hydrogenation of $\alpha$-pinene to cis-pinane over Ru nanocatalysts in aqueous micellar nanoreactors. RSC Adv. 2016, 6, 54806-54811. [CrossRef]

7. Lee, L.-C.; Lu, J.; Weck, M.; Jones, C.W. Acid-Base Bifunctional Shell Cross-Linked Micelle Nanoreactor for One-Pot Tandem Reaction. ACS Catal. 2016, 6, 784-787. [CrossRef]

8. Vriezema, D.M.; Aragones, M.C.; Elemans, J.A.A.W.; Cornelissen, J.J.L.M.; Rowan, A.E.; Nolte, R.J.M. Self-Assembled Nanoreactors. Chem. Rev. 2005, 105, 1445-1489. [CrossRef] [PubMed]

9. Baleizão, C.; Garcia, H. Chiral Salen Complexes: An Overview to Recoverable and Reusable Homogeneous and Heterogeneous Catalysts. Chem. Rev. 2006, 106, 3987-4043. [CrossRef] [PubMed]

10. Jacobsen, E.N. Catalytic Asymmetric Synthesis; Ojima, I., Ed.; VCH: Weinheim, Germany, 1993; Chapter 4.2, pp. 159-202.

11. Yoon, T.P.; Jacobsen, E.N. Privileged Chiral Catalysts. Science 2003, 299, 1691-1693. [CrossRef] [PubMed]

12. Arends, I.W.E.E. Metal-Catalyzed Asymmetric Epoxidations of Terminal Olefins Using Hydrogen Peroxide as the Oxidant. Angew. Chem. Int. Ed. 2006, 45, 6250-6252. [CrossRef] [PubMed]

13. McMorn, P.; Hutchings, G.J. Heterogeneous enantioselective catalysts: Strategies for the immobilisation of homogeneous catalysts. Chem. Soc. Rev. 2004, 33, 108-122. [CrossRef] [PubMed]

14. Shi, Z.-H.; Li, N.-G.; Shi, Q.-P.; Tang, Y.-P.; Tang, H.; Shen, M.-Z.; Duan, J.-A. Immobilization of Chiral Manganese(III)-salen Complexes for Enantioselective Epoxidation of Unfunctionalised Olefins. Curr. Org. Synth. 2014, 11, 204-243. [CrossRef]

15. La Paglia Fragola, V.; Lupo, F.; Pappalardo, A.; Trusso Sfrazzetto, G.; Toscano, R.M.; Ballistreri, F.P.; Tomaselli, G.A.; Gulino, A. A surface-confined $\mathrm{O}=\mathrm{MnV}$ (salen) oxene catalyst and high turnover values in asymmetric epoxidation of unfunctionalized olefins. J. Mater. Chem. 2012, 22, 20561-20565. [CrossRef]

16. Trusso Sfrazzetto, G.; Millesi, S.; Pappalardo, A.; Toscano, R.M.; Ballistreri, F.P.; Tomaselli, G.A.; Gulino, A. Olefin epoxidation by a (salen)Mn(III) catalyst covalently grafted on glass beads. Catal. Sci. Technol. 2015, 5, 673-679. [CrossRef]

17. Ballistreri, F.P.; Brinchi, L.; Germani, R.; Savelli, G.; Tomaselli, G.A.; Toscano, R.M. Enantioselective epoxidations of alkenes catalyzed by (salen)Mn(III) in aqueous surfactant systems. Tetrahedron 2008, 64, 10239-10243. [CrossRef]

18. Ballistreri, F.P.; Gangemi, C.M.A.; Pappalardo, A.; Tomaselli, G.A.; Toscano, R.M.; Trusso Sfrazzetto, G. (Salen)Mn(III) Catalyzed Asymmetric Epoxidation Reactions by Hydrogen Peroxide in Water: A Green Protocol. Int. J. Mol. Sci. 2016, 17, 1112-11121. [CrossRef] [PubMed]

19. Bérubé, C.; Barbeau, X.; Lagüe, P.; Voyer, N. Revisiting the Juliá-Colonna Enantioselective Epoxidation: Supramolecular Catalysis in Water. Chem. Commun. 2017, 53, 5099-5102. [CrossRef] [PubMed]

20. Malkov, A.V.; Czemerys, L.; Malyshev, D.A. Vanadium-Catalyzed Asymmetric Epoxidation of Allylic Alcohols in Water. J. Org. Chem. 2009, 74, 3350-3355. [CrossRef] [PubMed]

21. Colladon, M.; Scarso, A.; Strukul, G. Towards a Greener Epoxidation Method: Use of Water-Surfactant Media and Catalyst Recycling in the Platinum-Catalyzed Asymmetric Epoxidation of Terminal Alkenes with Hydrogen Peroxide. Adv. Synth. Catal. 2007, 349, 797-801. [CrossRef] 
22. Li, J.; Hu, F.; Xie, X.-K.; Liu, F.; Huang, Z.-Z. Synthesis of new functionalized chiral ionic liquid and its organocatalytic asymmetric epoxidation in water. Catal. Commun. 2009, 11, 276-279. [CrossRef]

23. Prasad, S.; Achazi, K.; Bottcher, C.; Haag, R.; Sharma, S.K. Fabrication of nanostructures through self-assembly of non-ionic amphiphiles for biomedical applications. RSC Adv. 2017, 7, 22121-22132. [CrossRef]

24. Morotti, T.; Calabrese, V.; Cavazzini, M.; Pedron, D.; Cozzuol, M.; Licciardello, A.; Tuccitto, N.; Quici, S. Zirconium phosphate/phosphonate multilayered films based on push-pull stilbazolium salt: Synthesis, characterization and second harmonic generation. Dalton Trans. 2008, 2974-2982. [CrossRef] [PubMed]

25. Tuccitto, N.; Giamblanco, N.; Licciardello, A.; Marletta, G. Patterning of lactoferrin using functional SAMs of iron complexes. Chem. Commun. 2007, 2621-2623. [CrossRef] [PubMed]

26. Gulino, A.; Trusso Sfrazzetto, G.; Millesi, S.; Pappalardo, A.; Tomaselli, G.A.; Ballistreri, F.P.; Toscano, R.M.; Fragalà, L. Nerve Gas Simulant Sensing by an Uranyl-Salen Monolayer Covalently Anchored on Quartz Substrates. Chem. Eur. J. 2017, 23, 1576-1583. [CrossRef]

27. Ballistreri, F.P.; Condorelli, G.G.; Fragalà, I.; Motta, A.; Pappalardo, A.; Tomaselli, G.A.; Tudisco, C.; Trusso Sfrazzetto, G. Covalent functionalization of silicon surfaces with cavitand-modified salen. Eur. J. Inorg. Chem. 2011, 2124-2131. [CrossRef]

28. Amato, M.E.; Ballistreri, F.P.; D'Agata, S.; Pappalardo, A.; Tomaselli, G.A.; Toscano, R.M.; Trusso Sfrazzetto, G. Enantioselective Molecular Recognition of Chiral Organic Ammonium Ions and Amino Acids Using Cavitand-Salen Based Receptors. Eur. J. Org. Chem. 2011, 5674-5680. [CrossRef]

29. Kleij, A.W. Nonsymmetrical Salen Ligands and Their Complexes: Synthesis and Applications. Eur. J. Inorg. Chem. 2009, 193-205. [CrossRef]

30. Pappalardo, A.; Amato, M.E.; Ballistreri, F.P.; Tomaselli, G.A.; Toscano, R.M.; Trusso Sfrazzetto, G. Pair of Diastereomeric Uranyl Salen Cavitands Displaying Opposite Enantiodiscrimination of $\alpha$-Amino Acid Ammonium Salts. J. Org. Chem. 2012, 77, 7684-7687. [CrossRef] [PubMed]

31. D’Urso, A.; Tudisco, C.; Ballistreri, F.P.; Condorelli, G.G.; Randazzo, R.; Tomaselli, G.A.; Toscano, R.M.; Trusso Sfrazzetto, G.; Pappalardo, A. Enantioselective extraction mediated by a chiral cavitand-salen covalently assembled on a porous silicon surface. Chem. Commun. 2014, 50, 4993-4996. [CrossRef] [PubMed]

32. Ballistreri, F.P.; Pappalardo, A.; Toscano, R.M.; Tomaselli, G.A.; Trusso Sfrazzetto, G. A New Heteroditopic Chiral Uranyl-Salen Receptor for Molecular Recognition of Amino Acid Ammonium Salts. Eur. J. Org. Chem. 2010, 20, 3806-3810. [CrossRef]

33. Pappalardo, A.; Ballistreri, F.P.; Li Destri, G.; Mineo, P.G.; Tomaselli, G.A.; Toscano, R.M.; Trusso Sfrazzetto, G. Supramolecular Polymer Networks Based on Calix[5]arene Tethered Poly(p-phenyleneethynylene). Macromolecules 2012, 45, 7549-7556. [CrossRef]

34. Giuffrida, M.L.; Rizzarelli, E.; Tomaselli, G.A.; Satriano, C.; Trusso Sfrazzetto, G. A novel fully water-soluble $\mathrm{Cu}(\mathrm{I})$ probe for fluorescence live cell imaging. Chem. Commun. 2014, 50, 9835-9838. [CrossRef] [PubMed]

35. Tuccitto, N.; Trusso Sfrazzetto, G.; Gangemi, C.M.A.; Ballistreri, F.P.; Toscano, R.M.; Tomaselli, G.A.; Pappalardo, A.; Marletta, G. Memory-Driven Order-Disorder Transition of 3D-Supramolecular Architecture Based on Calix[5]arene and Porphyrin Derivatives. Chem. Commun. 2016, 52, 11681-11684. [CrossRef] [PubMed]

36. Puglisi, R.; Ballistreri, F.P.; Gangemi, C.M.A.; Toscano, R.M.; Tomaselli, G.A.; Pappalardo, A.; Trusso Sfrazzetto, G. Chiral Zn-salen complexes: A new class of fluorescent receptors for enantiodiscrimination of chiral amines. New J. Chem. 2017, 41, 911-915. [CrossRef]

37. Kurti, L.; Blewett, M.M.; Corey, E.J. Origin of Enantioselectivity in the Jacobsen Epoxidation of Olefins. Org. Lett. 2009, 11, 4592-4595. [CrossRef] [PubMed]

38. Bulman Page, P.C.; Chan, Y.; Armylisas, A.H.N.; Alahmdi, M. Asymmetric epoxidation of chromenes mediated by iminium salts: Synthesis of mollugin and $(3 S, 4 R)$-trans-3,4-dihydroxy-3,4-dihydromollugin. Tetrahedron 2016, 72, 8406-8416. [CrossRef]

39. Epoxidation reactions with 6-CN-2,2-dimethylchromene, 1,2-dihydronaphthalene and cis- $\beta$-ethylstyrene were carried out also without phosphate buffer (in the same condition of entry 4, 9 and 17 reported in Table 1), obtaining the same results of conversion and enantiomeric excess measured in the presence of phosphate buffer.

40. We performed epoxidation of 6-CN-2,2-dimethylchromene without 1-Mn, with CTABr $=[0.06]$, [alkene] = $[\mathrm{NaClO}]=1.17 \times 10^{-2} \mathrm{M}, 0.05 \mathrm{M} \mathrm{Na}_{2} \mathrm{HPO}_{4}$ at $\mathrm{pH} 11.2$, obtaining a conversion of $52 \%$ after $1 \mathrm{~h}$, and $100 \%$ after $6 \mathrm{~h}$; with 1,2-dihydronaphthalene, with the same conditions, conversion value was $38 \%$ after $1 \mathrm{~h}$ and $100 \%$ after $12 \mathrm{~h}$ while with cis- $\beta$-ethylstyrene we observed $47 \%$ of conversion after $1 \mathrm{~h}$ and 100 after $8 \mathrm{~h}$. 
41. Van Aken, K.; Strekowski, L.; Patiny, L. EcoScale, a semi-quantitative tool to select an organic preparation based on economical and ecological parameters. Beilstein J. Org. Chem. 2006. [CrossRef] [PubMed]

42. Gałuszka, A.; Konieczka, P.; Migaszewski, Z.M.; Namiesnik, J. Analytical Eco-Scale for assessing the greenness of analytical procedures. Trends Anal. Chem. 2012, 37, 61-72. [CrossRef]

43. Scheurer, A.; Mosset, P.; Spiegel, M.; Saalfrank, R.W. Reverse asymmetric catalytic epoxidation of unfunctionalized alkenes. Tetrahedron 1999, 55, 1063-1078. [CrossRef]

2018 by the authors. Licensee MDPI, Basel, Switzerland. This article is an open access article distributed under the terms and conditions of the Creative Commons Attribution (CC BY) license (http://creativecommons.org/licenses/by/4.0/). 